\title{
Prevalence of HBV and HIV coinfection from an infectious disease hospital in Mumbai
}

\author{
Jayanthi Shastri", Nita Gangurde, Manish Pathak, Sandhya Sawant, Sachee Agrawal \\ From 2nd International Science Symposium on HIV and Infectious Diseases (HIV SCIENCE 2014) \\ Chennai, India. 30 January - 1 February 2014
}

\section{Background}

Hepatitis B virus (HBV) and HIV coinfection are pressing health problems in developing countries including India. Concurrent infection with HBV may alter the natural history and treatment of both diseases. Hepatitis B and HIV frequently coexist due to common modes of transmission. HIV and HBV coinfection leads to complex immunopathological disorder heralding poor prognosis and dismal outcomes. The present study was aimed to examine the prevalence of HIV and HBV co- infection among hospitalized patients.

\section{Methods}

Two groups of population were studied; group I $(n=1000)$ hospitalized adult patients with clinical jaundice were tested for HBsAg by ELISA. HBsAg positive patients were further tested for HIV infection as per NACO guidelines. Group II $(n=650)$ hospitalized patients with symptoms like fever $>1$ month, weight loss $>10 \%$, cough $>3$ weeks and lymphadenopathy were tested for HIV as per NACO guidelines. HIV positive patients were further tested for HBsAg by ELISA.

\section{Results}

In group I, $10 \%$ were positive for HBsAg and out of 100 HBsAg positive $6 \%$ were co infected with HIV. In group II, $15.38 \%$ were positive for HIV and out of 100 HIV positive $25 \%$ were co- infected with HBV. Overall co infection is $15.5 \%$ with male preponderance and heterosexual mode of transmission being the commonest.

\section{Conclusion}

HIV and HBV share common modes of transmission, therefore all HIV positive patients should be screened

\footnotetext{
* Correspondence: jsshastri@gmail.com

Department of Microbiology, TN Medical College and BYL Nair Charitable Hospital, Mumbai, India
}

C 2014 Shastri et al; licensee BioMed Central Ltd. This is an Open Access article distributed under the terms of the Creative Commons Attribution License (http://creativecommons.org/licenses/by/4.0), which permits unrestricted use, distribution, and reproduction in any medium, provided the original work is properly cited. The Creative Commons Public Domain Dedication waiver (http:// creativecommons.org/publicdomain/zero/1.0/) applies to the data made available in this article, unless otherwise stated.

\section{and take full advantage of:}

- Convenient online submission

- Thorough peer review

- No space constraints or color figure charges

- Immediate publication on acceptance

- Inclusion in PubMed, CAS, Scopus and Google Scholar

- Research which is freely available for redistribution Submit your manuscript at
www.biomedcentral.com/submit C BioMed Central 